\title{
Heavy Metals contents in Neem Tree (Azadirachta indica) Parts and Surroundings
}

\author{
Ideisan I Abu-Abdoun ${ }^{1 *}$ and Zohuir A Al-Balawna ${ }^{2}$ \\ ${ }^{1}$ Department of Chemistry, University of Sharjah, Sharjah, UAE \\ ${ }^{2}$ National Laboratory Department, Ministry of Climate change and Environment Sharjah, UAE \\ *Corresponding Author: Ideisan I Abu-Abdoun. E-mail: abuabdoun@sharjah.ac.ae
}

Received: July 10, 2019; Published: July 17, 2019

DOI: $10.31080 /$ ASMS.2019.03.0358

\begin{abstract}
The heavy metal content in neem (Azadirachta indica) samples were analyzed using ICP-OES technique and different samples such as neem leaf, neem wood and neem gum were collected from the university of Sharjah, university city. The environmental pollution can be monitored using metal content in different neem samples easily grown in UAE. The metal contents of $\mathrm{Fe}, \mathrm{Mn}, \mathrm{Co}, \mathrm{Ni}$, $\mathrm{Cu}, \mathrm{Zn}, \mathrm{Cr}, \mathrm{Cd}, \mathrm{Pb}, \mathrm{Mo}, \mathrm{As}, \mathrm{B}, \mathrm{Ca}$ were analyzed using ICP-OES method. The average metal concentrations of different samples in ppm were Fe (155.48), Mn (8.63), Co (0.12), Ni (1.42), Cu (7.11), Zn (5.91), Cr (0.63), Cd (0.02), Pb (0.50), Mo (0.91), As (1.85), B (68.09), Ca (10832.07) respectively.

The environmental pollution arises from different ways such as hazard gases released into the atmosphere due to factories, contaminated water release in seas (or) river and deposition of heavy metals in soils, plants. These contaminations effect the earth atmosphere, leads to climate change, increase salinity of sea water and heavy metal deposition. The neem plants absorb carbon dioxide and maintains the balance between the $\mathrm{CO}_{2}$ and $\mathrm{O}_{2}$ on the earth atmosphere. By using the photosynthesis, these plants produce more amount of oxygen by absorbing $\mathrm{CO}_{2}$. These plants were acted excellent air filters and absorb polluted gaseous present in the environment and other advantages of neem plants, they can survive in heat, water pollution and used as a soil fertilizer. The toxicity due to the different kind of pollution in the atmosphere was low, shows the healthier environment in the area located in the University of Sharjah, university city.
\end{abstract}

Keywords: Heavy Metals; Neem Parts; Environmental Pollution.

\section{Introduction}

Importance of heavy metals was steadily increasing in cities as a consequence of air contamination in the environment arise health risks [1]. Current studies shown that natural vegetation was useful in observing the atmospheric metal outgrowth [2]. Reports of contamination of metals due to plant residues in industrial areas and cities have an excessive amount of micronutrient such as $\mathrm{Zn}$ and $\mathrm{Cu}[3,4]$. The pollution of the environment due to heavy metal concentration was carried out geochemical studies by collecting dust and soil samples.

The possible ways of people exposed to high levels of trace metals are inhalation of dust particles and swallow of soils and dust (in case of children). The Atmosphere of cities influence on people's health as well as the quality of life [5].
According to reports, the accumulation of world population increased in urban areas by the next 30 years. The elevated pollution levels due to industrial centers and irresponsible industrial actions put an impact on the city environment [6].

The sources of deposition of trace metals in the urban atmosphere due to domestic business, factories and city traffic collected in plants, soils and polluted water was examined [7].

The source of heavy metal contamination in an urban environment can vary anthropogenic sources in different ways, such as the combustion of fossil fuel, city traffic, metallurgical factories, and other industries [8]. Pollution particles can be composed of elements such as $\mathrm{Zn}, \mathrm{Pb}, \mathrm{Cr}, \mathrm{Cu}$ [9]. 
Air pollution in the cities arise in many ways such as combustion coal, pesticides reuse cremation and use the age of leaded gasoline [9] the content of $\mathrm{Pb}$ deposition leads to lichens measures the level of $\mathrm{Pb}$ in street traffic [10]. The other factors also influence the plants due to air pollution [11].

According to the survey, the levels of $\mathrm{Cu}, \mathrm{Zn}$, and Fe found higher in herbs such as white clover than paspalum [12] the main source of cadmium pollution is due to utilization of residual water for irrigation as well as use age constitutes of fertilizers [13].

The pollution due to $\mathrm{Cu}$ come from many sources such as industries, automobile, and soils [14]. The changes in the environments can be monitored using plant species or plants related to biological organisms. Few plants are very sensitive to single or more toxicants present in the atmosphere, these plants are grown to detect the effect on pollution, are called biomonitoring plants. They have a potential advantage to illustrate the presence of phytotoxicity in the environmental air and also indicate the spatial spreading of pollution effects. Monitoring needs standard methods to measure pollution air [15].

Plants accumulate the heavy metals in their tissue but released into the surrounding atmosphere. The uptake amount was depending on the genotype of the plants, there are two types of plants named as excluders and includes. The excluder plants uptake low amount of metals, even external concentrations are very high. These plants build a barrier to control the uptake of the element, but the outside concentrations are very high. The barrier loses its role, increasing toxic metal concentration. In which the includes or accumulators' plants, they can deposit more levels of metals even though the outside concentration were very low. This kind of plants have detoxification technique builds within the tissues, which permit the plant to deposit large levels of metals. The includes the uptake accumulation of elements not increased, if the external concentrations increased.

A distinct kind of accumulators called hyperaccumulator, which illustrate the greater deposition of metal content in the leaves of the plants. for example, the metal content in leaves in (mg/g) shown as $>0.1$ for $\mathrm{Cd}>1$ for $\mathrm{Pb}, \mathrm{Co}, \mathrm{Cu}$, Ni or $>10$ for $\mathrm{Mn}$ and $\mathrm{Zn}$ [16].

The heavy metal contamination in the environment arises from different factors such, the release of pollution in water or soils and air. Many heavy metals were toxic nature, but other metals are essential for living such as $\mathrm{Fe}, \mathrm{Zn}, \mathrm{Cu}, \mathrm{Co}$, and $\mathrm{Cr}$, were needed for the metabolic activities for the main class of organisms. Depending upon daily intake some heavy metals are necessary micronutrients for plants, animals, and various micro-organism [17].
The present study shows the concentration of heavy metals and biomonitoring of elements in lichen plant. The samples collected from the neem trees trunk, leaves and gum in the University of Sharjah UAE for the analysis of heavy metal concentration.

\section{Materials}

Area of the study

Sharjah is the third large city of UAE, located in the southern coast of the Arabian Gulf of Arabian Peninsula, known for its nation's cultural capital. The economic growth of $7.4 \%$ of the GDP contributes to UAE. In 2016 WHO officially accounted as a healthy city [18]. In summer the temperature reaches $40^{\circ} \mathrm{C}$ with $50 \%$ humidity. The google map shows samples collection for the present study.

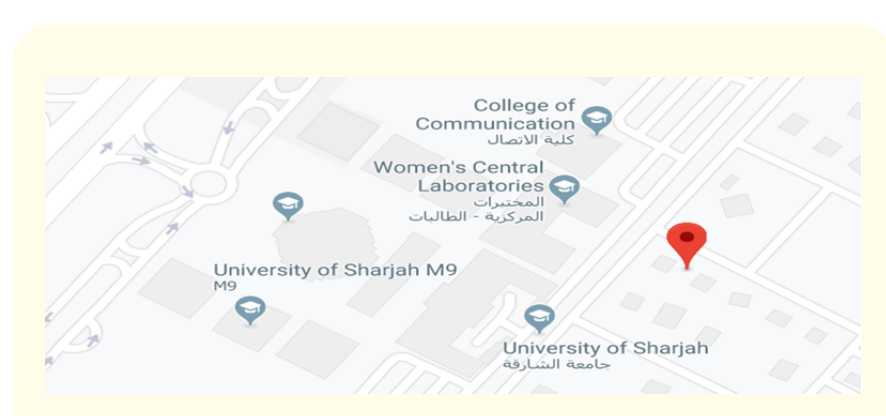

https://www.google.com/maps/place/25\%C2\%B017'14.4\% $22 \mathrm{~N}+55 \% \mathrm{C} 2 \% \mathrm{~B} 028$ '45.6\%22E/@25.2873268,55.4771547,17z/ data $=$ !3m1!4b1!4m5!3m4!1s0x0:0x0!8m2!3d25.2873268!4d55.4 793434 ?hl=en

Sample collection

The samples of Neem (A. indica) tree trunk bark, leave, and gum collected in January 2019 from the University of Sharjah situated in the university city, Sharjah. The analysis of the samples (bark and leaves) collected by using a stainless-steel knife. The samples were stored in polyethylene bags and named according to Radojevic and Bashkin (1999). (19) The standards prepared for the determination of $\mathrm{Cd}, \mathrm{Pb}, \mathrm{Zn}, \mathrm{C}$, and Ni using ICP-OES method.

\section{Sample digestion}

The sample was digested using wet digestion method, one gram of sample taken into keddahs flask having the $1000 \mathrm{~cm} 3$ capacity and the sample was digestion in 3:1 ratio of $\mathrm{HCl}$ and $\mathrm{HNO}_{3}$ and leave for a whole day inside a fume hood. The mixture heated for $40^{\circ} \mathrm{C}$ for more than half hour, the heat was increased up to $100^{\circ} \mathrm{C}$ and heating continued till the solution become clear, and the white fumes disappeared indicates the completion of the digestion process [20]. 
The digestion solution diluted with distilled water and boiled about 15 minutes. The solution was cooled, and filter using Whatman filter paper and filled till the mark of keddahs flask using distilled water. The digested solution transferred into a polyethylene bottle for further analysis of heavy metal concentration using ICPOES.

\section{Preparation of standard solutions}

Zinc Standard solutions preparation: One gram of zinc metal was dissolved in $30 \mathrm{ml}$ of $5 \mathrm{M} \mathrm{HCl}$ solution and diluted to $1000 \mathrm{ml}$ with deionized water. From this stock solution of zinc, standard diluted solutions of $2 \mathrm{ppm}$ to $25 \mathrm{ppm}$ prepared.

Cadmium standard solutions preparation: A stock solution of cadmium was prepared by dissolving $2.0360 \mathrm{~g}$ of cadmium chloride in $250 \mathrm{ml}$ of deionized water and diluted to $1000 \mathrm{ml}$ in a volumetric flask. From the stock solution of cadmium, standard, dilute solutions ranging from $0 \mathrm{ppm}$ to $10 \mathrm{ppm}$ prepared.

Lead standard solution Preparation: A stock solution of lead was prepared by dissolving $1.60 \mathrm{~g}$ Lead (II) nitrate $\left(\mathrm{Pb}\left(\mathrm{NO}_{3}\right)_{2}\right)$ in $20 \mathrm{ml}$ of deionized water and diluted to $1000 \mathrm{ml}$ in a volumetric flask. From the stock solution of lead, standard, dilute solutions ranging from 0 ppm to 10 ppm prepared.

Nickel standard solution preparation: A stock solution of Nickel was prepared by dissolving $4.9530 \mathrm{~g}$ of Nickel nitrate $\left(\mathrm{Ni}\left(\mathrm{NO}_{3}\right)_{2}\right)$ in $1000 \mathrm{ml}$ of deionized water and diluted to $1000 \mathrm{ml}$ in a volumetric flask. From the stock solution of Nickel, standard, dilute solutions ranging from $0 \mathrm{ppm}$ to $10 \mathrm{ppm}$ prepared.

Chromium standard solution preparation: A stock solution of chromium was prepared by dissolving $7.6960 \mathrm{~g}$ of Chromium nitrate $\left(\mathrm{Cr}\left(\mathrm{NO}_{3}\right)_{3} \cdot 9 \mathrm{H}_{2} \mathrm{O}\right)$ in $250 \mathrm{ml}$ of deionized water and diluted $1000 \mathrm{ml}$ in a volumetric flask. From the stock solution of chromium, standard, dilute solutions ranging from $0 \mathrm{ppm}$ to $10 \mathrm{ppm}$ prepared.

\section{Results and Discussion}

The heavy metal concentrations of neem gum, neem wood, and neem leaf presented in Table 1 . The metal contents of Fe, Mn, Co, $\mathrm{Ni}, \mathrm{Cu}, \mathrm{Zn}, \mathrm{Cr}, \mathrm{Cd}, \mathrm{Pb}, \mathrm{B}$, Ca were analyzed using ICP-OES technique. In this study, three neem wood, two neem gum, and three neem leaf samples collected from the University of Sharjah, university city for the analysis. The neem leaf samples contain a high amount of $\mathrm{Fe}, \mathrm{Co}, \mathrm{Ni}, \mathrm{Zn}, \mathrm{Cr}, \mathrm{Cd}, \mathrm{As}, \mathrm{B}, \mathrm{Ca}$, while gum samples have a high content of $\mathrm{V}$ and $\mathrm{Mg}$, and wood samples have greater levels of $\mathrm{Co}$, Mn, and Mo.

The maximum value of heavy metals found in our study were in ppm as follows Co was 0.21 present in leaf (L3),Cu was 13.66 present in wood(W3),Ni was 2.40 present in leaf (L3), Cr was 1.33 present in leaf (L3), As was 5.54 present in leaf (L3), Zn was 13.44 present in leaf (L3), Mo was 2.97 present in wood(W3), Pb was 0.79 present in leaf (L3), $\mathrm{V}$ was 6.27 present in gum(G1), and Cd was equally present in seven samples as 0.01 respectively.

\begin{tabular}{|c|c|c|c|c|c|c|c|c|c|c|c|c|c|}
\hline Sample & $\begin{array}{c}\text { Fe } \\
(p p m)\end{array}$ & $\begin{array}{c}\text { Mn } \\
(\mathbf{p p m})\end{array}$ & $\begin{array}{c}\text { Co } \\
\text { (ppm) }\end{array}$ & $\begin{array}{c}\mathrm{Ni} \\
(\mathbf{p p m})\end{array}$ & $\begin{array}{c}\mathrm{Cu} \\
(\mathrm{ppm})\end{array}$ & $\begin{array}{c}\mathrm{Zn} \\
(\mathbf{p p m})\end{array}$ & $\begin{array}{c}\mathrm{Cr} \\
(\mathbf{p p m})\end{array}$ & $\begin{array}{c}\text { Cd } \\
(\mathbf{p p m})\end{array}$ & $\begin{array}{c}\mathrm{Pb} \\
(\mathrm{ppm})\end{array}$ & $\begin{array}{c}\text { Mo } \\
\text { (ppm) }\end{array}$ & $\begin{array}{c}\text { As } \\
\text { (ppm) }\end{array}$ & $\begin{array}{c}\text { B } \\
\text { (ppm) }\end{array}$ & $\begin{array}{c}\text { Ca } \\
\text { (ppm) }\end{array}$ \\
\hline $\begin{array}{l}\text { neem } \\
\text { wood1 } \\
\text { (w1) }\end{array}$ & 158.66 & 7.20 & 0.16 & 1.74 & 7.46 & 3.48 & 0.61 & 0.00 & 0.63 & 0.00 & 0.00 & 28.85 & 8611.59 \\
\hline $\begin{array}{l}\text { neem } \\
\text { wood2 } \\
\text { (w2) }\end{array}$ & 131.14 & 6.04 & 0.14 & 1.53 & 6.57 & 2.85 & 0.44 & 0.01 & 0.58 & 0.00 & 0.00 & 28.21 & 7575.47 \\
\hline $\begin{array}{l}\text { neem } \\
\text { wood3 } \\
\text { (w3) }\end{array}$ & 148.66 & 16.67 & 0.11 & 1.42 & 13.66 & 7.08 & 0.81 & 0.11 & 0.49 & 2.97 & 4.52 & 23.48 & - \\
\hline $\begin{array}{l}\text { neem } \\
\text { gum 1(g1) }\end{array}$ & 131.61 & 3.99 & 0.10 & 1.20 & 9.38 & 2.98 & 0.92 & 0.01 & 0.42 & 2.43 & 4.75 & 4.16 & - \\
\hline $\begin{array}{l}\text { neem } \\
\text { gum 2(g2) }\end{array}$ & 92.81 & 2.68 & 0.08 & 0.88 & 4.96 & 3.66 & 0.27 & 0.01 & 0.26 & 0.00 & 0.00 & 3.31 & 7667.00 \\
\hline $\begin{array}{l}\text { neem } \\
\text { leaf1(l1) }\end{array}$ & 79.71 & 7.16 & 0.04 & 0.61 & BDL & 5.10 & 0.18 & 0.01 & 0.25 & 0.00 & 0.00 & 121.15 & 11188.15 \\
\hline $\begin{array}{l}\text { neem } \\
\text { leaf2(12) }\end{array}$ & 171.37 & 9.87 & 0.13 & 1.58 & 2.42 & 8.68 & 0.45 & 0.01 & 0.61 & 0.00 & 0.00 & 117.60 & 19118.16 \\
\hline $\begin{array}{l}\text { neem } \\
\text { leaf3(13) }\end{array}$ & 329.87 & 15.41 & 0.21 & 2.40 & 5.32 & 13.44 & 1.33 & 0.01 & 0.79 & 1.89 & 5.54 & 217.91 & - \\
\hline
\end{tabular}

Table 1: Heavy metal concentration of Neem tree. 
In the present study iron levels in neem samples ranges from 79.71- 329.87ppm. In lettuce (357.78 $\left.\mu \mathrm{gg}^{-1}\right)$ and spinach $(211.00$ $\mu g g-1)$ contain a low content of Iron [21]. According to Yahaya and Amusan, the concentration of Fe was $1075.79 \mu \mathrm{gg}-1$, in cocoyam leaves (211.64 $\mu \mathrm{gg}-1)$, was nearly the same compared to the present study $[22,23]$. The amount of Fe in plants ranging from 500.00$100.00 \mu \mathrm{gg}-1$ recommended by ICAR [24].

The concentration of $\mathrm{Mn}$ in neem samples ranging between 2.68-16.67ppm. These levels compared with different studies. The amount of $\mathrm{Mn}$ in neem was higher compared to spinach $(7.00 \mu \mathrm{gg}$ $\left.{ }^{1}\right)$, lettuce $\left(7.50 \mu \mathrm{gg}^{-1}\right)$ [21], while spinach leaves $\left(165.00 \mu \mathrm{gg}^{-1}\right)$ contains significantly higher levels of Mn reported by Miller-ihli and Baker [25]. Usually, the concentration of Mn normal in dry mass of plants lies within the range 500.00-25.00 ggg-1 $^{-1}$ [24].

The content of $\mathrm{Ni}$ in the present study lies between 0.61 $-2.40 \mathrm{ppm}$. The Ni content in onion $\left(0.24 \mu \mathrm{gg}^{-1}\right)$, spinach $(0.69 \mu \mathrm{gg}-$ $1)$, bitter leaf $\left(0.86 \mu \mathrm{gg}^{-1}\right)$ and drum tree $\left(0.78 \mu \mathrm{gg}^{-1}\right)$ were lower compared to our neem samples [26].

\begin{tabular}{|l|c|c|c|c|c|c|c|c|}
\hline & Fe & Mn & Zn & Cr & Co & Pb & Ni & Cu \\
\hline Nigeria & $2-210$ & $12.0-37.0$ & $1.5-12.50$ & $0-30$ & $0.5-18$ & $0-5$ & $0-6$ & $0-3.50$ \\
\hline WHO & 425.0 & 500.0 & 100.0 & 2.30 & NS & 0.30 & NS & 40.0 \\
\hline present study & 155.48 & 8.63 & 5.91 & 0.63 & 0.12 & 0.30 & 1.42 & 7.11 \\
\hline
\end{tabular}

Table 2: Shows the metal content of different studies.

The results compared with other neem samples of Nigeria and WHO, in which the metal concentrations of $\mathrm{Fe}, \mathrm{Mn}, \mathrm{Zn}, \mathrm{Cr}, \mathrm{Co}, \mathrm{Pb}$, $\mathrm{Ni}, \mathrm{Cu}$ were low. The samples were taken from the university city, Sharjah, the covered with the many plants, non-industrial, noncommercial, far from highways. In the year 2016, the world health organization declared the Sharjah city as a healthy city, with low air pollution [18].

Several studies show that the monitoring of pollution using metal deposition in plants and neem plants are medicinal plants, deposited the heavy metal content and good absorber of $\mathrm{CO}_{2}$ from the atmosphere.

\section{Conclusion}

The present study shows the heavy metals content in neem leaves, wood, gum samples using ICP-OES, and the samples collected from the University of Sharjah (UAE). The higher concentration of metals such as $\mathrm{Fe}, \mathrm{Co}, \mathrm{Ni}, \mathrm{Zn}, \mathrm{Cr}, \mathrm{Cd}, \mathrm{As}, \mathrm{B}, \mathrm{Ca}$ found in neem leaves compared to neem gum and neem wood. The heavy metal concentrations within the permissible limit suggested by WHO.

The pollution causing due to automobiles, factories and release a vast amount of $\mathrm{CO}_{2}$ and $\mathrm{NO}$ into the air causes earth atmosphere warmer. These lead to global warming or climate change and increases sea levels, as well as change the pattern of rainfall and affect food production. The neem plantation absorbs carbon dioxide and maintains the balance between the $\mathrm{CO}_{2}$ and $\mathrm{O}_{2}$ on the earth atmosphere. By using the photosynthesis, these plants produce more amount of oxygen by absorbing $\mathrm{CO}_{2}$. These plants were acted excellent air filters and absorb polluted gaseous present in the environment and other advantages of neem plants they can survive in heat water pollution and used as a soil fertilizer. The toxicity due to the different kind of pollution in the atmosphere was low, shows the healthier environment in the area located in the University of Sharjah, university city.

\section{Acknowledgment}

Support to this work from University of sharjah(UOS) and MCCAE UAE is gratefully acknowledged.

\section{Bibliography}

1. Kutaba-Pendias A and Pendias H. "Trace metals in soils and plants”. 2nd edn. CRC Press, USA (1992): 356.

2. Goodman GT and Roberts TM. "Plant, and Soil as indicators of metals in the air". Nature 231 (1971): 287-292.

3. Ruhling A and Tyler G. "Sorption and retention of heavy metals in the woodland moss Hylocomium splendens (Hedw)". Oikos 21.1 (1970): 92-97.

4. Ruhling A and Tyler G. "Heavy Metal Deposition in Scandinavia”. Water, Ai, and Soil Pollution 2.4 (1973): 445-455. 
5. Bartnicki J., et al. "Atmospheric transport and deposition of heavy metals over Europe, comparison of model results and observations. 10th International Conference on Heavy Metals in the Environment, Hamburg, Germany (1995).

6. N Population Division (UNDP) "World urbanization prospects”. The 1999 Revision (2001).

7. Whitton BA. "Toxocity of heavy metals to freshwater algae". A Review Phykos 9 (1970): 116-125.

8. Shakour AA and Eil-Taieb NM. "Heavy metals in Atmospheric particulate in the industrial Area North Cairo Egypt". Air pollution Department National Research Centre, Dokki, Cairo, Egypt (1995).

9. Butler JD. "Air Pollution". Chemistry Academic Press, London, 2nd edn, (1979): 1-20.

10. Laaksovirta K and Silvola J. "Effect of air pollution by Copper, Sulphuric acid, and fertilizer factories on plants at Harjavalta, West Finland". Ann Bot Fennici 12 (1975): 81-88.

11. Heck WW and Dunning JA. "The effect of Ozone on tobacco and pinto bean as conditioned by several ecological factors". Journal of the Air Pollution Control Association 17.2 (1967): 112-114.

12. Beavington F. "Contamination of soil with Zinc, Copper, Lead, and Cadmium in the Wollongong City Area". Australian Journal of Soil Research 11 (1973): 27-31.

13. Jaakkola A., et al. "The Effect of cadmium contained in fertilizers on the cadmium content of vegetables". Agricultural and Food Science 51 (1979): 158-162.

14. Fergusson JE. "Inorganic Chemistry and the Earth". Wheaton and Co. Ltd. Exeter,Chapter 13 (1982): 348.

15. ISEB. "Biomonitoring of Air Pollutants with Plants. International Society of Environmental Botanists. Home Environ". News Internship Conference 11 (2005): 2.

16. Baker AJM., et al. "Metal hyperaccumulator plants: a review of the ecology and physiology of a biological resource for phytoremediation of metal -polluted soil". In Phytoremediation. (Eds Terry N and Banuelos G, S). Lewis Publishers, Boca Raton. (2000): 85-108,
17. Agarwal SK. "Heavy Metal Pollution". APH Publishing (2009): 270.

18. Sharjah officially named WHO Healthy City. Sharjah (2016).

19. Radojevc M and Bashin NV. "Practical Environmental Analysis. (Royal Society of Chemistry and Thomas Graham House, Cambridge (1999): 180-430.

20. Audu AA and Lawal AO. "Variation in Metal Contents of Plants in Vegetable garden sites in Kano Metropolis". Journal of Applied Sciences and Environmental Management 10.2 (2005): 105-109.

21. Sani HA., et al. "Toxic metals uptake by spinach (Spinacea oleracea) and lettuce (Lactuca sativa) cultivated in Sokoto. A comparative study". Conference proceedings of Chemical Society of Nigeria at 34th Annual International Conference, Workshop and Exhibition (2011): 363-369.

22. Amusan AA., et al. "Characteristics of soils and crops uptake of metals in municipal waste dump sites in Nigeria". Journal of Human Ecology 17.3 (2005): 167-171.

23. Yahaya Y. "Study of the environmental effects on the nutrient's compositions of some selected vegetables in Aliero Agricultural fields". A Ph.D. proposal submitted to Chemistry Department Usman Dan Fodiyo University Sokoto (2009).

24. Codex Alimenatrius Commission. Food additives and contaminants. Joint FAO/WHO/ICAR Food Standard Programming. A LINORN 01/12A. (2006): 1-289.

25. Miller-ihli JN and Baker AS. "Food and dairy products applications of Atomic Spectroscopy and spectrometry". 1, Academic Press (AP) London (2000): 583-588.

26. Omogbehin SA and Osesua BA. "The level of trace metals in selected vegetable crops collected from Birnin-Kebbi market, Birnin-kebbi, Nigeria". Conference proceedings of Chemical Society of Nigeria at 34th Annual International Conference,Workshop and Exhibition (2011): 201-201.

\section{Volume 3 Issue 8 August 2019 \\ (C) All rights are reserved by Ideisan I Abu-Abdoun and Zohuir A Al-Balawna.}

